\title{
An Analysis on Social Studies Teacher Candidates' Hospital Service Practice Experiences
}

\author{
Dr. Öğr. Üyesi Türkan ÇELİK* \\ Kilis 7 Aralık Üniversitesi, Muallim Rıfat Eğitim Fakültesi, Türkçe ve Sosyal Bilimler Eğitimi Bölümü, \\ Kilis / Türkiye, turkancelik@kilis.edu.tr, ORCID: 0000-0001-8380-9419
}

\begin{abstract}
The aim of this study is to determine the opinions of prospective social studies teachers about hospital experiences within the scope of Community Service Practices (CSP) Course. For this purpose, the study was designed in a phenomenological design, which is one of the qualitative research methods. The sample of the study was determined by using criterion sampling technique. In this context, $103^{\text {rd }}$ grade social studies prospective teachers participated in the CSP course. In the hospital environment, prospective teacher carried out many activities such as helping elderly, orphaned, children, disabled and refugee patients to find the right department for them and answering the questions asked by the patients in the hospital, accompanying the patients, and helping the hospital staff. The opinions of the prospective teachers about their experiences in the hospital were obtained through a semi-structured interview forms at the end of the activities. The data were subjected to content analysis and the theme and sub-themes were obtained from the opinions of prospective teachers. These themes were; "To raise awareness for the patient and the hospital", "To experience spiritual satisfaction in the process of helping", "Willingness to take responsibility in the hospital" and "Change of prejudices about the patient and the hospital". It was found that the experiences of prospective teachers about the activities in the hospital environment were generally positive. This result also shows that prospective teachers gained awareness about social problems and worked willingly and voluntarily to be a part of
\end{abstract}

* Sorumlu Yazar. Tel: +90 $3488142666 / 1722$

Makale Tarih Bilgisi. Gönderim: 01.11.2019, Kabûl: 22.08.2020, Erken Görünüm: 15.04.2021, Basım: Aralık, 2021

(C) 2021. Kalem Eğitim ve Sağlık Hizmetleri Vakfı. Bütün Hakları Saklıdır. ISSN: 2146-5606, e-ISSN: 2687-6574. 
the solution of these problems.

Keywords: Community service practices course; Social studies teaching; Social studies teacher candidates; Service in hospital.

\title{
Sosyal Bilgiler Öğretmen Adaylarının Hastahanede
}

\section{Hizmet Uygulaması Deneyimlerinin İncelenmesi}

\begin{abstract}
$\ddot{\mathbf{O z}}$
$\mathrm{Bu}$ çalışmanın amacı Sosyal Bilgiler öğretmen adaylarının Topluma Hizmet Uygulamaları (THU) dersi kapsamında hastane deneyimlerine ilişkin düşüncelerini tespit etmektir. Bu amaç doğrultusunda çalışma nitel araştırma yöntemlerinden fenomonolojik desende tasarlanmıştır. Çalışmanın örneklemi amaçlı örneklem tekniklerinden ölçüt örneklem tekniği ile belirlenmiştir. Bu bağlamda THU dersinde topluma sunacakları hizmeti hastane ortamında gerçekleştirecek on sosyal bilgiler 3. s1nıf öğretmen adayı katılmıştır. Öğretmen adaylarının hastane ortamında yaşl1, kimsesiz, çocuk, engelli ve mülteci hastalara hastanede gidecekleri bölümü gösterme, hastanedeki bölümlere ilişkin hastaların sordukları soruları yanitlama, onlara refakat etme ve hastane personeline yardım etme şeklinde birçok etkinlik gerçekleştirilmiştir. Çalışmaların sonunda yarı yapılandırılmış görüşme formları aracılığıyla öğretmen adaylarından hastanedeki deneyimlerine ilişkin düşünceleri alınmıştır. Elde edilen veriler içerik analizine tabi tutularak öğretmen adaylarının görüşlerinden tema ve bu temalara bağlı olarak alt temalara ulaşılmıştır. Ulaşılan temalar: hasta ve hastaneye yönelik farkındalık geliştirmek; yardım etme sürecinde manevi doyum yaşamak; hastanede sorumluluk almada isteklilik ve hasta ve hastaneye ilişkin ön yargılarının değişmesi şeklindedir. Öğretmen adaylarının hastane ortamındaki etkinliklere ilişkin deneyimlerinin genel anlamda olumlu olduğu bulgulanmıştır. $\mathrm{Bu}$ sonuç ayrıca öğretmen adaylarının toplumsal sorunlar konusunda hem farkındalık kazandıklarını hem de bu sorunların çözümünün bir parçası olmada istekli ve gönüllü bir şekilde çalıștıklarına ilişkin deneyimler yaşadıklarını göstermektedir.
\end{abstract}

Anahtar Kelimeler: Topluma hizmet uygulamaları dersi; Sosyal bilgiler öğretimi; Sosyal bilgiler öğretmen adayları; Hastahanede hizmet.

\section{Introduction}

Young individuals in today's world are expected to be sensitive active citizens who are indifferent to social events, problems, and their environment. From this point of view, individuals need to be aware and conscious of being 
sensitive to some problems in society, producing solutions and taking an active role in the elimination of these problems. Although all the courses given in schools are important, Social Studies course, which serves the process of healthy socialization of the individual and being an active citizen of the society, is even more important. Educating individuals who have the consciousness and awareness of serving the society in this sense at a younger age is undoubtedly dependent on teachers who have this experience and understanding. In this context, it is ensured that prospective teachers take a practical role in the social service processes in the faculties of education with the Community Service Practices (CSP) course (1 hour theoretical, 2 hours practical) decided to be taught in the faculties of education in the 2006-2007 academic year and started to be implemented in 2008-2009 academic year. CSP course is an experiential form of learning (Crews, 1995). The course designed in the form of experiential learning, supports students' desired behaviors such as academic achievement, personal development and social responsibility, and serves as a cooperative learning and teaching strategy platform (Bender, 2006). Although the CSP course was popular in the United States (US) initially, it has recently begun to be applied in different countries, including Turkey (Kesten, Elma, Kıroğlu, Dicle, Uzun and Palavan, 2011). However, the roots of this new practice under the name of CSP go back to village institutes, which serve as a place of civic welfare, solidarity, cooperation in the Seljuk and Ottoman tradition (Elma, Kesten, Kıroğlu, Uzun, Dicle and Palavan, 2010) and providing villagers with information on cultural and economic issues through a practical application bridging the school and the village (Başaran, 2006). Through the CSP course in which universities try to meet their social responsibilities to society to a large extent (Horzum and Bektaş, 2012), prospective teachers also develop self-esteem, self-efficacy, selfawareness and positive perspectives towards the teaching profession, gain valuable information about other individuals in the society, and develop strong communication skills (Wade, 1997). This course, which supports the active participation of students in the activities, also contributes to the process of the implementation of the constructivist approach (Bhaerman, Cordell and Gomez, 1998; Billig and Kraft, 1998) and the fulfillment of the responsibilities of the schools in the process of raising responsive citizens. In fact, Riedel (2002) stated that one of the most important benefits of CSP programs is to provide young people with democratic citizenship skills and the main purpose of CSP programs should be raising participatory/active citizens. In this sense, 
it could be noted that CSP and social studies curriculum have common ground. In fact, social studies are an elementary education course which is formed by integrating different social sciences fields in order to ensure the socialization of the individual and to be a good citizen (Zarrillo, 2004). In the Social Studies Course, the life of the human being as a society, its behavior, basic needs, the ways of meeting them, the studies done to meet the needs and related institutions are discussed (Kısakürek, 1987). Another aim is to raise individuals who adopt democratic values, adapt to the society they live in, are sensitive to the problems of the society, are aware of their rights and responsibilities and who have developed social participation skills (MEB, 2018). In this context, it is seen that social service practices and social sciences curriculum cannot be considered separately from each other in terms of learning areas, content, goals, and values and skills that should be gained within the scope of social studies course. As a matter of fact, when the 2018-2019 social studies curriculum is examined (MEB, 2018), it can be seen that the achievements of "relates the individual and social needs and the institutions that serve these needs" in the context of "effective citizenship" learning area, and the achievement of "participates in activities supporting social cooperation and solidarity in the formation of social unity" in the context of "individual and society" learning area emphasize social service practices. In addition, the program includes empathy, communication, cooperation, realizing stereotyping and prejudice skills, and these overlap with the values of solidarity, sensitivity, respect, love, responsibility and helpfulness. Therefore, studies for the implementation of the CSP course, which is closely intertwined with the learning outcomes, learning areas, values and skills of the social studies course, are important for social studies teachers. In the literature, it was found that in some of the studies on the CSP course, the participants generally expressed positive opinions about the practices in the CSP course (Akkocaoğlu, Albayrak and Kaptan, 2010; Dinçer, Ergül, Şen and Çabuk, 2011; Elma et al., 2010; Özdemir and Tokcan, 2010; Sönmez, 2010; Y1lmaz, 2011). In addition, it was determined that CSP course made significant contributions to the development of skills related directly to democratic attitudes and values such as social sensitivity, responsibility, communication, teamwork, problem solving, and participation in non-governmental organizations (Özdemir and Tokcan, 2010; Waldstein and Reiher, 2001; Y1lmaz, 2011). In the context of the current research, there were also studies in which the CSP was conducted only in the context of social studies teachers (Aykırı, 2017; Beldağ, Yaylacı, Gök and İpek, 2015; Bulut 
and Kara, 2012; Çetin and Sönmez, 2009; Gökçe, 2011; Kara, Altıntaş and Kaya, 2017; Kesten, Koçer and Egüz, 2014; Sönmez, 2010). These studies conducted with social studies teachers reported that prospective teachers gained achievements more in line with the aim and content of the course and contributed to the subjects such as "social skills development" (Sönmez, 2010), increased their sensitivity to social problems and contributed to their personal development (Gökçe, 2011), the participants generally had positive thoughts in terms of subjects covering the course aim and context (Çetin and Sönmez, 2009) and that the values gained in this process addressed the affective field and contributed to the internalization of these values and transformation into behavior with concrete practices (Kara, Altıntaş and Kaya, 2017). However, in some of the studies on CSP course that were conducted with social studies teacher candidates, problems related to the process were emphasized. Problems such as insensitivity and negative attitudes of the public, bureaucratic problems, negative attitudes and attitudes of the institution/organization authorities, difficulty of the target audience (patient, disabled, etc.), the need to visually prove the effectiveness, transportation and meeting needs, identifying the target audience and activities (Aykır1, 2017), lack of interest in projects (Beldağ, Yaylacı, Gök and İpek, 2015), problems in organizing, and inability to continue the activities started in the course due to concerns about nationwide exams such as KPSS and ALES (Kesten, Koçer and Egüz, 2014) can be listed. In this study, the institution/place where the applications were made within the scope of the CSP course was placed at the center. The experiences of prospective teachers gained from the activities carried out in this institution (hospital) were investigated.

\section{Significance of the Research}

The experiences of social studies teacher candidates after the practices carried out in the hospital in the CSP course became the main interest of this study. It is thought that in-depth determination of social studies teacher candidates' views about the hospital project, which is one of the application centers in the CSP course, will contribute to the field. In this sense, in the study, among the social studies teacher candidates taking the CSP course, only those who realized their activities and applications within the scope of the "hospital" project were selected. In this way, opinions about experiencing the phenomenon of serving in the hospital environment will be obtained from prospective teachers. Hospital environment is one of the most important institutions in the society and affected by war, fight, tragedy, epidemic, old age, deprivation or 
other sociological cases; therefore, how the experiences gained in the hospital environment within the scope of the CSP course will help prospective teachers in gaining consciousness and awareness in the process of social awareness and becoming an active citizen is important. In light of these findings that are also important for this research, certain changes can be made in the services provided in the hospital environment or in the application process within the scope of the CSP course. Therefore, this study, which was designed with a phenomenological research design, is thought to make significant contributions to the field.

\section{Objective}

The aim of this study is to determine the experiences of social studies teacher candidates during the "hospital" project within the scope of community service practices course, where they provide assistance and referral services to the patients (especially elderly, disabled, Syrian, women, children, and illiterate patients). The research question created within this context is as follows: What are the opinions of prospective social studies teachers about their experiences in hospital service practice?

\section{Method}

This research was conducted with the qualitative research method. Qualitative research method aims to present perceptions and events in their environment in a realistic and comprehensive way by using data collection techniques such as observation, interview, and document analysis (Yıldirım and Şimşek, 2013). Descriptive phenomenology was used as the basis of this study in order to correctly determine the quality of the experiences of prospective teachers in the hospital environment. Phenomenology includes an epistemological perspective and is a research design that feeds on philosophical and psychological understanding (Ersoy, 2017). "Phenomenology", a methodological and in-depth depiction of how people experience phenomena (Patton, 2014), is often used in qualitative research focusing on human experiences. It is observed that most of the definitions in the literature for phenomenological research emphasize similar points. In this context, the phenomenological design is based on researching cases that we are not completely unfamiliar with but cannot fully comprehend (Yıldırım and Şimşek, 2013) and illustrating the participants' perceptions of this situation, case, or phenomenon (Reiners, 2012). In this study, perceptions of social studies teacher candidates towards the phenomenon of voluntary service activities in the hospital will be 
described.

\section{Study Group}

Prospective teachers who took the CSP course in the fall semester of 2018-2019 academic year participated in this study. "Criterion sampling", one of the purposeful sampling techniques, was used in sample selection. Criterion sampling is based on the study of all cases that already exist or meet certain criteria determined by the researcher (Yıldırım and Şimşek, 2013). During the design phase of this study, some criteria for the selection of participants were determined by the researcher. These criteria are taking the CSP course, being a third-grade social studies teacher candidate, and performing the activities in the hospital project. A total of 10 social studies teacher candidates participated in the study, 7 of them were female and 3 of them were male.

\section{The Process of Experiencing Hospital Activities}

The process of experiencing hospital activities by social studies teacher candidates began with the distribution of groups to faculty members in the faculty. The participant group of the responsible faculty member came together with the instructor during the theoretical hours of this course and brainstormed on what kind of services could be provided to the society. In the following period, a few of the students mentioned the people in the hospital environment. The need of these people for referral, assistance and guidance practices was discussed. After confirming this situation with preliminary observations, the necessary formal procedures were followed and permissions were obtained for the implementation. At the beginning of the application, the course supervisor visited the hospital management together with the prospective social studies teachers and shared the activities they were planning to do. Further proposals and support were obtained from hospital management. First of all, a person working in the hospital gave orientation training to social studies teacher candidates for one week about the units of the hospital, the characteristics of the units and the general operation of the hospital. The prospective teachers who acquired knowledge about the procedures and units in the hospital divided the tasks among themselves. In order to serve all patients, the students were divided into different parts of the hospital: the entrance, emergency department, polyclinics, operating rooms, laboratories, toilets and etc. The services provided by prospective teachers in this process included referral, providing information, and accompanying refugees, illiterate patients, children, elderly, disabled, women, and patients coming to the hospital with 
stretchers and wheelchairs. In this process, social studies teacher candidates also assisted hospital staff by assuming roles in departments such as patient registration. Prospective teachers tried to provide services to sick citizens and assisted hospital operation with these services.

\section{Data Collection Tool}

A semi-structured interview form was used for data collection. In interview forms that are effective in uncovering situations that cannot be observed directly in humans (Patton, 2014), the aim is to enter the inner world of the individual and reveal all aspects of his or her perspective. In this study, after reviewing the literature, the researcher prepared interview questions about revealing prospective teachers' perceptions about the phenomenon of service activities in the hospital. After the measurement tool was prepared, expert opinions were obtained and the interview form was finalized. The data collection process was based on voluntarism.

\section{Data Analysis}

Study data was subjected to content analysis and tried to be described. The data collected from prospective teachers were systematically transcribed with a word processing program. The entire set of data was read by the researcher several times in general. After this step was completed, the data were analyzed by content analysis technique. Content analysis is a process of examining and interpreting voluminous qualitative materials within the context of their basic consistency (Patton, 2014), and also enables the detection and analysis of previously unclear patterns in the collected data (Yıldırım and Şimşek, 2013). After reading the data collected from the participants in general terms, sub-themes were determined by reading the data line by line to determine the smallest meaningful units in the data set. Based on meaning relationships and similarities, sub-themes were gathered under themes representing larger patterns. After the analysis process was completed, sub-themes that emerged were presented in the findings section under main themes. Participant expressions, which consisted of themes and sub-themes, were also included in this study. In order to avoid confusion during the quotation process from the data set, representative codes such as K1, K2, K3, etc. were assigned to the participating teacher candidates.

\section{Results}

Findings obtained during the research process are presented in this section of the study. Four different themes have been obtained from the study 
data, in which social studies teacher candidates' experiences of serving the society within the scope of hospital practice were examined. As shown in Figure 1 below, these themes are "raising awareness for the patient and the hospital", "experiencing spiritual satisfaction during the process of helping", "willingness to take responsibility in the hospital" and "changing prejudices about the patient and the hospital".

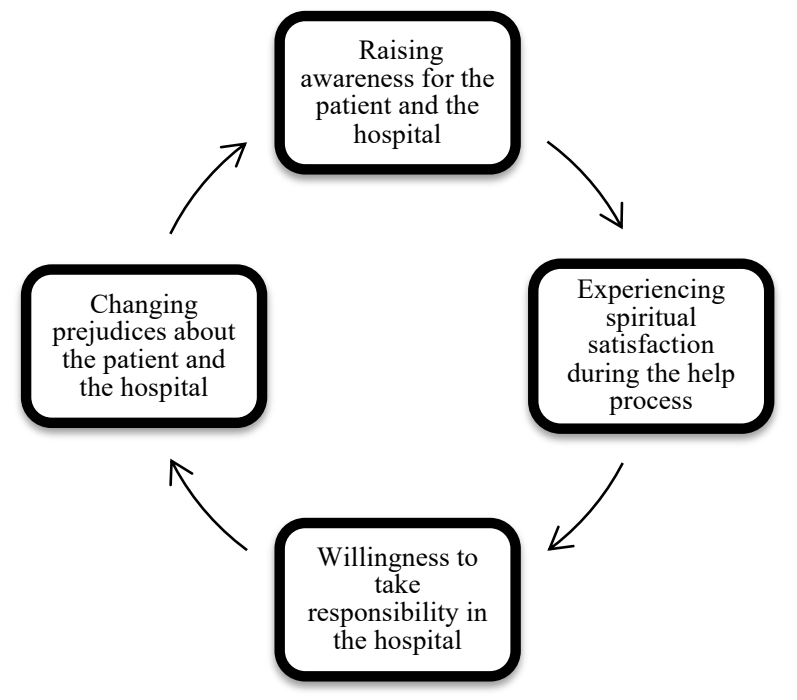

Figure 1. Themes Obtained from the Analysis of Research Data

In this part of the study, the sub-themes that make up each theme will be examined. The codes consisting of the experiences of the prospective teachers about the application process in the hospital will be presented in tables and the participant statements regarding the codes will be presented in the same way by quotation.

\section{Theme 1: Raising Awareness for The Patient and The Hospital}

One of the themes reached from the interview data of the prospective teachers was "raising awareness for the patient and the hospital". According to the Turkish Language Association (2021) the word patient means someone who is physically or mentally damaged due to illness, accident, injury, and needs treatment. Considering the meaning of the word patient, it can be said that people coming to the hospital environment, where the sick people are treated, are in need of physical or mental health services. Therefore, young, old, women, men, children, people with disabilities or refugees can form these sick people. In addition to the fact that the human profile of the patients 
coming to the hospital environment is different, the complaint and the severity of the health problem also change for each patient. In addition, the seriousness of the health problems of the people who come to the hospital, destitution, illiteracy, disability, or refugee status brings with them the need for assistance in the hospital environment. In this theme of the research, sub-themes and statements showed that the prospective teachers "raised awareness towards the hospital".

Table 1. The Theme of "Raising Awareness for The Patient and The Hospital" and Sub-Themes in This Context

\begin{tabular}{|c|c|c|}
\hline Theme & Sub-theme & Participants \\
\hline \multirow{10}{*}{$\begin{array}{l}\text { Raising } \\
\text { Awareness } \\
\text { for the } \\
\text { Patient } \\
\text { and the } \\
\text { Hospital }\end{array}$} & Witnessing the satisfaction of patients & $\mathrm{K} 1, \mathrm{~K} 3, \mathrm{~K} 5, \mathrm{~K} 6, \mathrm{~K} 7, \mathrm{~K} 10$ \\
\hline & $\begin{array}{l}\text { Witnessing the vast majority of people in need of } \\
\text { help }\end{array}$ & $\mathrm{K} 1, \mathrm{~K} 2, \mathrm{~K} 3, \mathrm{~K} 5, \mathrm{~K} 10$ \\
\hline & Empathizing with patients & $\mathrm{K} 1, \mathrm{~K} 2, \mathrm{~K} 10, \mathrm{~K} 5, \mathrm{~K} 6$ \\
\hline & Gaining awareness about the hospital and patients & $\mathrm{K} 1, \mathrm{~K} 9, \mathrm{~K} 5, \mathrm{~K} 8$ \\
\hline & Recognizing the importance of health & $\mathrm{K} 1, \mathrm{~K} 9, \mathrm{~K} 10$ \\
\hline & Witnessing different problems of people & $\mathrm{K} 1, \mathrm{~K} 2, \mathrm{~K} 4$ \\
\hline & $\begin{array}{l}\text { Witnessing the vast majority of patients in need of } \\
\text { referral }\end{array}$ & $\mathrm{K} 5, \mathrm{~K} 8, \mathrm{~K} 3$ \\
\hline & Witnessing traumatic events & $\mathrm{K} 3, \mathrm{~K} 8$ \\
\hline & Seeing the shyness of the patients & K5 \\
\hline & $\begin{array}{l}\text { Recognizing the importance of communication } \\
\text { that needs to be established with patients }\end{array}$ & K6 \\
\hline
\end{tabular}

"In the days we went to the hospital for the project, I started to think about what really matters in life. I realized the importance of communication and empathy with patients. I learned a lot about life." (K10)

"From the first day of my practice to the last day, I saw that patients, especially illiterate, disabled patients, elderly people, even literate patients without any disabilities had difficulty after coming the hospital. I saw that it was very difficult for disabled people to get to upper floors and travel around the hospital on their own." (K2)

"In fact, the summary of everything in life was in the hospital. We could not see that. When I realized this, I was so angry with myself for how I could not see the helplessness of people before. There were so many illiterate people in the hospital... Patients who did not know which department or which doctor to go, elderly patients who did not know where the toilets were..." (K8)

"A mother who had an accident with a motorcycle came to the emergency department of the hospital. But she was in shock. Her arm was being cast. Next to her was a scared little boy crying. I tried to calm the boy by holding him. She thanked me very much when I took him to the 
mother. These experiences helped me understand the vast majority of patients in the hospital that needed help." (K3)

\section{Theme 2: Experiencing Spiritual Satisfaction During the Process of Helping}

One of the themes obtained from the interview data was "experiencing spiritual satisfaction during the process of helping". The details of the spiritual satisfaction experienced can be observed in the sub-themes reached from the statements of teacher candidates. These sub themes were finding the practice useful, experiencing spiritual satisfaction, being happy performing the practice, the idea that the course is useful, feeling inner peace, feeling good with the practices, learning to be thankful through these practices, and being proud of yourself. When the statements in the sub-themes were also taken into consideration, the prospective teachers stated that the service they provided in the hospital provided them with valuable humane experiences.

Table 2. The Theme of "Experiencing Spiritual Satisfaction During the Process of Helping" and Sub-Themes in This Context

\begin{tabular}{lll}
\hline Theme & Sub-theme & Participants \\
\hline \multirow{3}{*}{$\begin{array}{l}\text { Experiencing } \\
\text { Spiritual }\end{array}$} & Finding the practice useful & $\mathrm{K} 2, \mathrm{~K} 5, \mathrm{~K} 7, \mathrm{~K} 9, \mathrm{~K} 6, \mathrm{~K} 10$ \\
\cline { 2 - 3 } $\begin{array}{l}\text { Satisfaction } \\
\text { During the }\end{array}$ & Experiencing spiritual satisfaction & $\mathrm{K} 1, \mathrm{~K} 9, \mathrm{~K} 7, \mathrm{~K} 8, \mathrm{~K} 3, \mathrm{~K} 10$ \\
\cline { 2 - 3 } $\begin{array}{l}\text { Process of } \\
\text { Helping }\end{array}$ & Being happy performing the practices & $\mathrm{K} 3, \mathrm{~K} 5, \mathrm{~K} 6, \mathrm{~K} 9, \mathrm{~K} 10, \mathrm{~K} 8$ \\
\cline { 2 - 3 } & The idea that the course if useful & $\mathrm{K} 1, \mathrm{~K} 6, \mathrm{~K} 7, \mathrm{~K} 9$ \\
\cline { 2 - 3 } & Feeling inner peace & $\mathrm{K} 1, \mathrm{~K} 2, \mathrm{~K} 10$ \\
\cline { 2 - 3 } & Leeling good with the practices & $\mathrm{K} 3, \mathrm{~K} 4, \mathrm{~K} 9$ \\
\cline { 2 - 3 } & Bearning to be thankful through these practices & $\mathrm{K} 6, \mathrm{~K} 9, \mathrm{~K} 10$ \\
\hline
\end{tabular}

"When I helped an elderly patient get a committee report, "My dear girl, do you have money to eat?" she said, "Let me give some money to you.". That made my eyes tear up. Even if we did not do anything, even if we just accompanied them to their destination with a smiling face, we would be receiving sentences such as "Blessing", "God bless you". And I realized that the best feeling in this life is the peace that fills you after you do well. This is indescribable. Helping the people there with pure faith and spending time with them was an activity that satiated the soul. It made us realize ourselves and be thankful for our health. The pride of helping people as much as I could for these 10 weeks was the best thing I got away with." (K1)

"Serving in the hospital taught me to be thankful. I understood that health was actually a blessing. I realized how good it was to help others; it made me feel so good. Guiding fearful, anxious people and turning that concern in their eyes into a smile on their faces is more valuable 
than many other things. I'm glad if I could help people and make things easier for them." (K9)

"I saw a wheelchair-bound elderly woman come to the hospital by herself. It was not because she did not have anybody, she was left alone. It was an indescribable feeling when she prayed for us after we helped her." (K8)

"When I was at the hospital, I saw an elderly woman who came to the hospital by herself. I told her I could help her. She told me she was looking for the orthopedic department. When I asked her what her disease was, I learned that it was related to neurosurgery instead of orthopedics. I told her that, and I took her an appointment from the neurosurgery department. After the examination, she started praying. I was very happy and felt very good. I realized what a beautiful project I was part of and how unique it was to help people." (K3)

\section{Theme 3: Willingness to Take Responsibility in The Hospital}

One of the themes obtained from the interview data of prospective teachers was "willingness to take responsibility". The word responsibility that comes to the forefront in the context of this theme means that the person accepts the consequences of his/her behaviors or situations under his/her authority and becomes fully accountable. This attribute is also important for the social studies education program with respect to the personal development of prospective social studies teachers, as well as the development of young individuals to whom they will instill "responsibility" during their education. In the context of this theme, several sub-themes were also identified during the services provided in the hospital environment. These are gaining the motivation to help, gaining a sense of mission, willingness to take part in the solution of the problems in the hospital, having information about the hospital units and their functioning, making the patients feel that they are not alone, and gaining communication skills in the hospital.

Table 3. The Theme of "Willingness to Take Responsibility in The Hospital" And Sub-Themes in This Context

\begin{tabular}{lll}
\hline Theme & Sub-theme & Participants \\
\cline { 2 - 3 } & Gaining the motivation to help & $\mathrm{K} 2, \mathrm{~K} 5, \mathrm{~K} 7, \mathrm{~K} 10, \mathrm{~K} 4$ \\
\cline { 2 - 3 } $\begin{array}{l}\text { Willingness to } \\
\text { Take }\end{array}$ & $\begin{array}{l}\text { Willining a sense of mission } \\
\text { Responsibility to take part in the solution of the }\end{array}$ & $\mathrm{K} 2, \mathrm{~K} 8, \mathrm{~K} 10$ \\
\cline { 2 - 3 } in the Hospital & $\begin{array}{l}\text { Having information about the hospital units and } \\
\text { their functioning }\end{array}$ & $\mathrm{K} 2, \mathrm{~K} 6, \mathrm{~K} 10$ \\
\cline { 2 - 3 } & Making the patients feel that they are not alone & $\mathrm{K} 3, \mathrm{~K} 6, \mathrm{~K} 7$ \\
\cline { 2 - 3 } & Gaining communication skills in the hospital & $\mathrm{K} 10$ \\
\hline
\end{tabular}


"After every patient I helped, my self-confidence increased. I tried to do whatever I could to reach out to more patients with the joy that I felt for doing good and being useful." (K1)

"A psychologist at the hospital liked our practice very much. Her patients were Syrians and did not know where to go. She was calling me. I was going to her and helping her patients. In other words, we were not only helping the patients but also the staff working there." (K7)

"When we went to the hospital for the community service course, we visited the hospital first. We found out what was where. Then we tried to help the patients. A lot of Syrian patients were coming in. They thought that I was an interpreter who worked there. They were asking me something in Arabic, and I was directing them to the interpreters. We helped them finish their appointments faster." (K6)

"For example, in the first week, an elderly aunt had to see some doctors and be examined at the hospital so that she could start receiving home care. She did not have a son, daughter or a relative with her. Maybe if I hadn't helped her, or if we hadn't done this practice, she wouldn't be able to get that service. After this incident I started going to the hospital with more enthusiasm." (K2)

"When we first went to the hospital, I and my other friends were excited. We didn't know exactly what we were going to do, so we walked around in the hospital, accompanied by a staff member, to get to know the units. Each of us was responsible for different units and tried to do our part there. At first, I had no idea how to communicate with the people who came to the hospital or how to help them. But I managed to overcome this in time." (K10)

\section{Theme 4: Changing Prejudices About the Patient and The Hospi-}

\section{tal}

Another theme obtained from the interview data was "changing prejudices about the patient and the hospital". The word "prejudice" that stands out in the context of this theme is defined previously acquired positive or negative judgment or preconceived opinion about a person, a thing and a situation within the context of certain conditions, events and images. Prospective teachers stated that there was a change in their preconceptions and prejudices for the patient and the hospital during the practice. As a matter of fact, one of the skills to be acquired in the context of the social studies curriculum is the ability to "realize stereotyping and prejudice". It can be much easier for a social studies teacher with this skill to teach the same skill to his or her students. Subthemes identified under this theme were changes in knowledge and judgment 
about the hospital, becoming sensitive about elderly and disabled people, and changing their preconceptions about the practices.

Table 4: The Theme of "Changing Prejudices About the Patient and The Hospital" And Sub-Themes in This Context

\begin{tabular}{lll}
\hline Theme & Sub-theme & Participants \\
\hline Changing & $\begin{array}{l}\text { Changes in knowledge and judgment about the } \\
\text { Prejudices }\end{array}$ & $\mathrm{K} 1, \mathrm{~K} 2, \mathrm{~K} 3, \mathrm{~K} 5$, \\
about the & Kospital & Becoming sensitive about elderly and disabled \\
\cline { 2 - 3 } $\begin{array}{l}\text { Patient and } \\
\text { the Hospital }\end{array}$ & \begin{tabular}{l} 
Keople \\
\cline { 2 - 3 }
\end{tabular} & Changes in the preconceptions about the practices \\
\hline
\end{tabular}

\begin{abstract}
"Before I started the practice in the hospital, I thought that the patients were examined when they went to the hospital and they took their medicines from the pharmacy and then they were done. I thought that the patients could easily reach the doctors and they could be examined without waiting. When I started the practice, I saw that was not the case. There, I wanted to help a person in need at any moment. In fact, this issue has affected me in such a way that I started helping the elderly or the disabled in the bus or elsewhere. I wasn't very attentive to these people before. Before I started the practice, I told myself 'what are you doing going to the hospital'. I thought the other practices were more fun and enjoyable. I thought ours (hospital practice) was very boring. However, during the practice process, I saw that helping people and receiving their blessing, seeing the smile on their faces is more enjoyable than any kind of game and entertainment. Many of my thoughts like this have changed with my practice experience in the hospital." (K2)

"When I first went to the hospital, I didn't think anyone needed help. I thought everyone knew where they were going. Or those who didn't brought someone with them who did. But day by day I saw it wasn't the case. We started helping people. At first I didn't think this project would be so nice." (K7)
\end{abstract}

\title{
Discussion, Conclusion and Recommendations
}

Everything that concerns the society and the people constitutes the content of social sciences. So much so that the Social Studies course is an elementary course created by the compilation of many other social science disciplines such as history, geography, economics, philosophy, anthropology, psychology, art history, law, sociology, etc. Undoubtedly, social studies teachers are individuals who are primarily responsible for the effective conduct of this course. In this respect, the education of social studies teachers in pre-service faculties should be organized in this sense. For this purpose, Community Service Practices course is given in teacher education. In fact, it is important that the architects of this course, which will ensure the healthy socialization of the 
individual, are aware of the society and the problems of the society and how they assume roles in the solution of these problems. In this respect, the work of prospective teachers during the CSP course taken at the universities offers important clues; because, with this course, universities try to meet their social responsibilities to society to a large extent (Horzum and Bektaş, 2012), and prospective teachers also develop self-esteem, self-efficacy, self-awareness and positive perspectives towards the teaching profession, gain valuable information about other individuals in the society, and develop strong communication skills (Wade, 1997). In this study, the opinions of prospective social studies teachers about the service process offered to the society within the hospital were obtained. During the interviews, themes such as "raising awareness for the patient and the hospital", "experiencing spiritual satisfaction during the process of helping", "willingness to take responsibility in the hospital" and "changing prejudices about the patient and the hospital" were obtained. One of these themes suggests that they "have developed awareness towards the hospital". The sub-themes identified under this theme were; witnessing the satisfaction of patients, witnessing the vast majority of people in need of help, empathizing with patients, gaining awareness about the hospital and patients, recognizing the importance of health, witnessing different problems of people ,witnessing the vast majority of patients in need of referral, witnessing traumatic events, seeing the shyness of the patients, and recognizing the importance of communication that needs to be established with patients. When the sub-themes were taken into consideration, it was found that prospective teachers understood that many patients actually needed these services in the hospital and that the patients' process became easier after help was provided. In addition to the opportunity to experience social problems closely, prospective teachers also tried to be a part of the solution in this process. This is consistent with the literature (Bhaerman, Cordell and Gomez, 1998; Billig and Kraft, 1998) that constructivist understanding is enabled by such experiences and at the same time, learning opportunities appropriate for the constructivist approach are created. Another theme obtained from the interview data was "experiencing spiritual satisfaction in the process of helping". The subthemes identified under this theme were finding the practice useful, experiencing spiritual satisfaction, being happy performing the practice, the idea that the course is useful, feeling inner peace, feeling good with the practices, learning to be thankful through these practices, and being proud of yourself. The statements "Helping the people there with pure faith and spending time 
with them was an activity that satiated the soul." (K1), "Guiding fearful, anxious people and turning that concern in their eyes into a smile on their faces is more valuable than many other things. I'm glad if I could help people and make things easier for them" (K9), and "I saw a wheelchair-bound elderly woman come to the hospital by herself. It was not because she did not have anybody, she was left alone. It was an indescribable feeling when she prayed for us after we helped her" (K8) all show that prospective teachers were generally satisfied with the activities and practices. This result is consistent with other studies where the participants in the CSP course expressed positive opinions about the course (Akkocaoğlu, Albayrak and Kaptan, 2010; Dinçer, Ergül, Şen and Çabuk, 2011; Elma et al., 2010; Sönmez, 2010; Özdemir and Tokcan, 2010; Y1lmaz, 2011). Another theme obtained from the research data was "willingness to take responsibility". In the context of this theme, several sub-themes were also identified during the services provided in the hospital environment. These were; gaining the motivation to help, gaining a sense of mission, willingness to take part in the solution of the problems in the hospital, having information about the hospital units and their functioning, making the patients feel that they are not alone, and gaining communication skills in the hospital. In the context of this theme, prospective teachers stated that the services they provided in the hospital provided them with valuable humane experience. These findings are in line with Bender's (2006) statement that this course, which is designed as experiential learning, also supports students' desired behaviors such as academic achievement, personal development and social responsibility. It was found that the activities performed by prospective teachers during the nine-week period broke down some prejudices about the patient and the hospital. In the context of changing prejudices about the patient and the hospital, several sub-themes such as changes in knowledge and judgment about the hospital, becoming sensitive about elderly and disabled people, and changing their preconceptions about the practices were identified. As a result, the experiences of prospective social studies teachers during the 9-week period of the hospital application process within the scope of the CSP course were described. Four themes, "raising awareness for the patient and the hospital", "experiencing spiritual satisfaction during the process of helping", "willingness to take responsibility in the hospital" and "changing prejudices about the patient and the hospital" were identified from these experiences. When the themes were taken into consideration, it was determined that the opinions of prospective teachers about their experiences were generally 
positive. Therefore, this process provided an opportunity for prospective teachers to familiarize themselves with the hospital environment that hosts different individuals with health problems in the society. In addition, it was found that prospective teachers gained awareness about social problems and worked willingly and voluntarily to be a part of the solution of these problems. In future studies, it is recommended to keep the experiences of prospective teachers in the forefront with respect to the activities carried out within the scope of the CSP Course.

\section{References}

Akkocaoğlu, N., Albayrak, A. and Kaptan, F. (2010, May). Topluma hizmet uygulamaları dersini alan ögretmen adaylarının toplumsal duyarlılık düzeyleri üzerine nitel bir çalışma (HÜ İlkögretim Bölümü örneği). Paper presented at the meeting of Uluslararası Öğretmen Yetiştirme Politikaları ve Sorunları Sempozyumu, II. Hacettepe Üniversitesi Eğitim Fakültesi ve Azerbaycan Devlet Pedagoji Üniversitesi, Beytepe, Ankara.

Aykırı, K. (2017). Sosyal bilgiler öğretmen adaylarının topluma hizmet uygulamaları dersi projelerine ilişkin deneyimlerinin belirlenmesi. Uluslararası Sosyal Bilgilerde Yeni Yaklaşımlar Dergisi, 1, 42-55.

Başaran, İ. E. (2006). Türk eğitim sistemi ve okul yönetimi. Ankara: Ekinoks Yayınevi.

Beldağ, A., Yaylacı, A. F., Gök, E. and İpek, C. (2015). Topluma hizmet uygulamaları dersinin üniversite-toplum iş birliği açısından değerlendirilmesi. Ahi Evran Üniversitesi Kırşehir Eğitim Fakültesi Dergisi, 2, 161-178.

Bender, G. (2006). Manual on service-learning for students. Pretoria: University of Pretoria, Faculty of Education Service-Learning.

https://repository.up.ac.za/bitstream/handle/2263/4971/Bender_Pathways(2007).pdf;jsessionid $=467472 \mathrm{DC} 5 \mathrm{AFFC} 4 \mathrm{C} 722647238 \mathrm{D} 87 \mathrm{~A} 651 \mathrm{~F}$ ? sequence $=1$

Bhaerman, R., Cordell, K. and Gomez, B. (1998). The role of service-learning in educational reform. Raleigh, NC: National Society for Experiential Education and Needham, MA: Simon and Shuster, Inc.

Billig, S. and Kraft, N. (1998). Linking federal programs and service-learning: A planning, implementation and evaluation guide. Lancaster, PA: Technomics Publishers.

Bulut, B. and Kara, C. (2012). Sosyal bilgiler dersinde topluma hizmet uygulamaları ve sosyal kulüplerle değerler eğitimi. M.Y. Eryaman, A. Kılınç, N. Cerrahoğlu, E. Yolcu, G. Ergen (Ed.), IV. Uluslararası Türkiye Eğitim Araştırmaları Kongresi (pp. 1621-1628). İstanbul: Yıldız Teknik Üniversitesi.

Crews, R. (1995). University of Colorado at Boulder service-learning handbook: What is service-learning? Boulder, CO: University of Colorado at Boulder.

Çetin, T. and Sönmez, Ö. F. (2009). Sosyal bilgiler öğretmen adaylarının topluma hizmet uygulamaları dersinin amaç ve içeriğine yönelik görüşlerinin değerlendirilmesi. G. Ü. Gazi Eğitim Fakültesi Dergisi, 29(3), 851-875.

Dinçer, Ç., Ergül, A., Şen, M. and Çabuk, B. (2011). Bir topluma hizmet uygulaması örneği: Haydi kavram oyuncaklarıyla oynayalım. Kastamonu Ĕgitim Dergisi, 19(1), 19-38. 
Elma, C., Kesten, A., Kıroğlu, K., Uzun, E. M., Dicle, A. N. and Palavan, Ö. (2010). Öğretmen adaylarının topluma hizmet uygulamaları dersine ilişkin algıları. Kuram ve Uygulamada Eğitim Yönetimi, 16(2), 231-252.

Ersoy, A. F. (2017). Fenomenoloji. In A. Saban and A. Ersoy, (Eds.), Eğitimde nitel araştırma desenleri (pp. 81-139). Ankara: Anı Yayıncılık.

Gökçe, N. (2011). Sosyal bilgiler öğretmen adaylarının topluma hizmet uygulamalarına ilişkin değerlendirmeleri. Uluslararası İnsan Bilimleri Dergisi, 8(2), 176194.

Horzum, M. B. and Bektaş, M. (2012). Otantik öğrenmenin topluma hizmet uygulamaları dersini alan öğretmen adaylarının derse yönelik tutum ve memnuniyetine etkisi. Kastamonu Eğitim Dergisi, 20(1), 341-360.

Kara, C., Altıntaş, A. and Kaya, İ. F. (2017). Sosyal bilgiler öğretmen adaylarının topluma hizmet uygulamalarıyla "yardımseverlik değeri” kazanmaları hakkındaki görüşleri. Akdeniz Eğitim Araştırmaları Dergisi, 22, 23-37.

Kesten, A., Elma, C., Kıroğlu, K., Dicle, A. N., Uzun, E. M. and Palavan, Ö. (2011). Kurum yöneticilerinin bakış açısıyla topluma hizmet uygulamaları. Elektronik Sosyal Bilimler Dergisi, 10(35), 45-63.

Kesten, A., Koçer, M. and Egüz, Ş. (2014). Topluma hizmet uygulamaları dersinin toplumsal bilinç oluşturmadaki etkisi. Uludă̆ Üniversitesi Eğitim Fakültesi dergisi, 27(2), 393-410.

Kısakürek, M. A. (1987). Sosyal bilgiler öğretiminin niteliği, kapsamı ve amaçları. In B. Özer, (Ed.), Sosyal bilgiler ögretimi (pp. 20-21) Eskişehir: Anadolu Üniversitesi Açıköğretim Fakültesi Yayınları.

Milli Eğitim Bakanlığı (2018). Sosyal bilgiler öğretim programı. http://mufredat.meb.gov.tr/Dosyalar/201812103847686SOSYAL\%20B\%C4\%B0LG \%C4\%B0LER $\% 20 \% \mathrm{C3} \% 96 \%$ C4\%9ERET\%C4\%B0M\%20PROGRAMI\%20.pdf.

Özdemir, S. M. and Tokcan, H. (2010). Topluma hizmet uygulamaları dersinin öğretmen adaylarının görüşlerine göre değerlendirilmesi. Selçuk Üniversitesi Ahmet Keleşoğlu Eğitim Fakültesi Dergisi, 30, 41-61.

Patton, M. Q. (2014). Nitel araştırma ve değerlendirme yöntemleri (3 ${ }^{\text {th }}$ ed.). (M. Bütün and S. B. Demir, Trans. Ed.). Ankara: Pegem Akademi. (Original work published 1999.)

Reiners, G. M. (2012). Understanding the differences between husserl's (descriptive) and heidegger's (interpretive) phenomenological research. Journal of Nursing \& Care, 1(119), 1-3.

Riedel, E. (2002). The impact of high school community service programs on students' feelings of civic obligation. American Politics Research, 30(5), 499527.

Sönmez, Ö. F. (2010). Sosyal bilgiler öğretmen adaylarının topluma hizmet uygulamaları dersine yönelik görüşlerinin kazanım boyutunda değerlendirilmesi. The Black Sea Journal of Social Sciences, 2(2), 53-73.

Wade, R. C. (1995). Developing active citizens: community service learning in social studies teacher education. Service Learning, General. Retrieved from http://digitalcommons.unomaha.edu/slceslgen/36.

Waldstein, F. A. and Reiher, T. C. (2001). Service learning and students' personal and civic development. Journal of Experiential Education, 24(1), 7-13. 
Yıldırım, A. and Şimşek, H. (2013). Sosyal bilimlerde nitel araştırma yöntemleri. Ankara: Seçkin Yayıncılık.

Yılmaz, K. (2011). Eğitim fakültelerinin sosyal sorumluluğu ve topluma hizmet uygulamaları dersi: Nitel bir araştırma. Kuramsal Eğitimbilim, 4(2), 86-108.

Zarrillo, J. J. (2004). Teaching elementary social studies principles and applications. New Jersey: Prentice Hall. 